Ann. Biol. anim. Bioch. Biophys., 1978, 18 (3), 699-709

\title{
Plasma calcitonin and parathyroid hormone levels in growing pigs on different diets. I. - High phosphorus diet
}

\author{
par A. POINTILLART, J. M. GAREL *, L. GUEGUEN \\ with the technical assistance of Colette COLIN \\ Station de Recherches de Nutrition, I. N. R. A., \\ 78350 jouy en Josas, France. \\ * Laboratoire de Physiologie du Développement, Université P.-et-M.-Curie, \\ 9, quai Saint-Bernard 75230 Paris Cedex 05, France.
}

Summary. Ten-week old growing pigs were fed a control diet containing 0.6 p. 100 phosphorus and then given a high phosphorus diet containing $1.15 \mathrm{p}$. 100 phosphorus. Two hours after the morning meal and 5 hrs later in the afternoon, plasma concentrations of calcium, magnesium, phosphorus, calcitonin and parathyroid hormone were studied during the 1-week control period, the first 3 weeks of high phosphorus diet, and 3 weeks later at slaughter. Plasma magnesium and calcitonin levels markedly increased during the first 2 weeks of high phosphorus diet, whereas afternoon plasma parathyroid hormone slightly decreased. Morning plasma calcitonin levels were higher than afternoon values during the high phosphorus period; afternoon plasma calcium concentrations were lower than morning values during the same period. Positive linear correlation was shown between plasma magnesium and plasma calcitonin levels during the high phosphorus period. Plasma phosphorus levels were not significantly affected by the phosphorus-rich diet. Changes in plasma magnesium, parathyroid hormone and calcitonin concentrations disappeared during the third week of high phosphorus diet, indicating the animals' adaptation. If is suggested that the high phosphorus diet induced temporary modifications in hormonal calcium-phosphorus regulation and that postprandial hypermagnesemia stimulated post-prandial calcitonin secretion, thus lowering afternoon plasma calcium levels. These results indicated that meal-effect of the high phosphorus diet or hypermagnesemia of nutritional origin could increase the calcitonin secretion.

\section{Introduction.}

A chronic excess of diefary phosphorus during long-term experiments increases the rate of bone resorption in rats (Anderson and Draper, 1972 ; Draper. Tien-Lin Sie and Bergan, 1972), mice (Shah, Krishnarao and Draper, 1967), dogs (Laflamme and Jowsey, 1972) and horses (Schryver, Hintz and Craig, 1971). Since in industrial pig production, the diet given is often rich in phosphorus, we used short-term experiments to compare the effect of a 0.6 p. 100 phosphorus control diet, commonly used for rearIng pigs in practical conditions, and a phosphorus-rich diet containing 1.15 p. 100 phosphorus. Little is known about the regulation of calcium-phosphorus metabolism 
in pigs. These animals have been used in many calcitonin (CT) studies, but attention was focussed on the role of divalent cations and gastrointestinal hormones (Care, 1965 ; Cooper ef al., 1972). No work has yet been done on the effects of different calcium and phosphorus intakes on plasma CT level. Likewise, there is no data in the literature on plasma parathyroid hormone (PTH) concentration in pigs on different diets.

In the present study, we measured plasma PTH and CT concentrations in order to determine the nutritional effects of dietary phosphorus content ; two phosphorus levels have been compared in the same animals.

\section{Material and methods.}

Animals and diets. - Four 10-week old Large-White male pigs weighing $17.2 \pm 0.5 \mathrm{~kg}$ were used. A chronically implanted catheter was fitted to collect blood samples twice daily from the jugular vein. The first blood sample was collected $2 \mathrm{hrs}$ after the morning meal and the second one $5 \mathrm{hrs}$ later to see if there was any meal effect or if a certain time lapse was necessary before changes could be observed. The afternoon meal was given just after the second blood puncture, i. e. 7 hrs after the morning meal. Blood punctures were done 5 days a week during 4 weeks, as well as at slaughter 3 weeks later; each sample was collected in a heparinized polyethylene tube maintained in an ice-bath. Samples intended for hormone assay were collected under peptidase inhibitors (Iniprol, Laboratoires Choay, Paris, France). After centrifugation at $4^{\circ} \mathrm{C}$, plasma samples were frozen at $-30^{\circ} \mathrm{C}$ until hormone assay.

During the first week the pigs were fed a control diet consisting of 72 p. 100 maize, 26 p. 100 soya meal and 2 p. 100 mineral-vitamin mixture. This diet contained 0.60 p. 100 phosphorus, 0.55 p. 100 calcium and 0.24 p. 100 magnesium.

During the next 6 weeks the animals received the same diet supplemented with monosodium and monocalcium phosphates. $\mathrm{P}, \mathrm{Ca}$ and $\mathrm{Mg}$ contents were then $1.15,0.77$ and 0.24 p. 100 respectively.

Plasma analysis. - Plasma calcium was measured by flame photometry (Eppendorf) and plasma magnesium by atomic absorption spectrophotometry (IL 151). Total plasma phosphorus was estimated as previously described (Guéguen and Besançon, 1972).

Plasma CT levels were measured by radioimmunoassay in a system already described in detail (Garel, Care and Barlet, 1974 ; Garel, Savajol and Barlet, 1976). This assay involved the use of purified porcine CT (Lot K 600-072F-2; 116 MRC units/mg ; Armour Pharmaceutical Co., Kankakee, Illinois, USA) for iodination through the chloramine-T method of Hunter and Greenwood (1962). The ${ }^{125}$-labelled porcine CT was purified by gel filtration on Sephadex G-50 fine. Specific activities of 200-300 $\mu \mathrm{Ci} / \mu \mathrm{g}$ were achieved routinely. The same batch of purified porcine CT was used at a final dilution of $1: 3000$; the tubes were incubated in an equilibrium system at $4^{\circ} \mathrm{C}$, and after 6 days were phase-separated on talcum powder. The sensitivity of the assay was $0.25 \mathrm{ng} / \mathrm{ml}$ plasma.

The plasma PTH level was also measured by radioimmunoassay using a bovine system already described (Garel and Barlet, 1976) which cross-reacted with porcine 
PTH. Purified bovine PTH (bPTH 1-84, a gift of J. A. Parsons and J. M. Zanelli, M. R. C., London, England) was labelled with ${ }^{125}$ using the chloramine-T method (Hunter and Greenwood, 1962) and purified through gel filtration on Sephadex G-50 fine. Standard curves were calibrated with pure bovine PTH (bPTH 1-84, a gift of G. D. Aurbach). An antibody, obtained in a goat against partially purified bovine PTH, was used at a final dilution of $1: 8000$. Since it did not cross-react with the synthetic bovine 1-34 fragment, this antibody was specific against the carboxyl terminal part of the PTH molecule. After incubation for 6 days at $4{ }^{\circ} \mathrm{C}$ in an equilibrium system, the bound and the free labelled fractions were separated by adsorption on plasma-coated char-

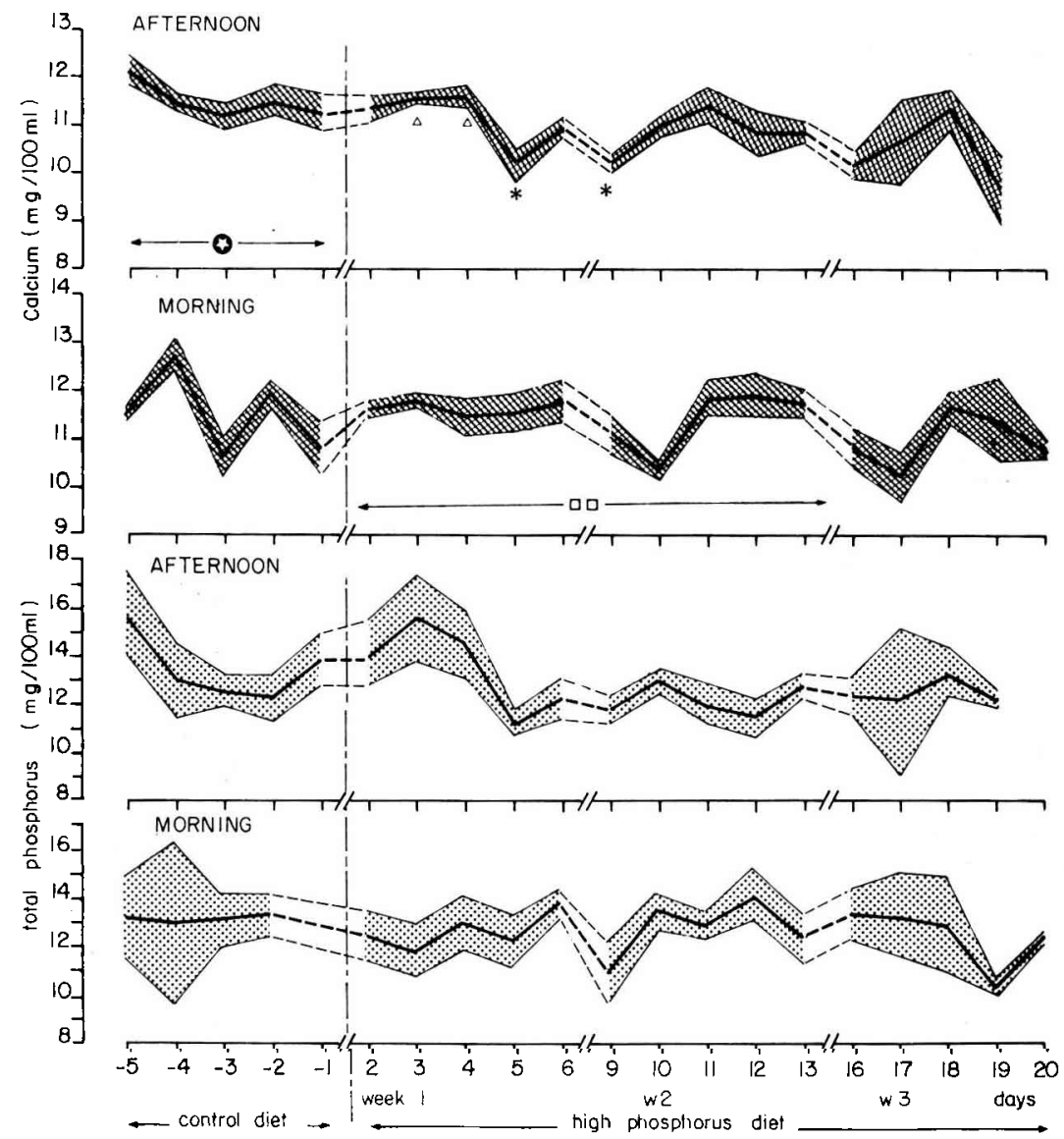

FIG. 1. - Morning ( $2 \mathrm{hrs}$ after the meal) and afternoon ( $7 \mathrm{hrs}$ after the meal) plasma concentrations of calcium and phosphorus in growing pigs fed a confrol and a high phosphorus diet $(m \pm$ s. e. $m$.).

- significantly higher than all high phosphorus period : $\mathrm{P}<0.05$, higher than week $2: P<0.01$ and higher than week $3: P<0.01$;

$\triangle$ significantly higher than day $5: P<0.05$;

* significantly lower than day -5 and $-2: P<0.05$;

CD significantly higher than corresponding afternoon period : $P<0.01$. 
coal. The results were expressed in $\mathrm{ng}$ equivalents bovine PTH per $\mathrm{ml}$ plasma. The sensitivity of the assay was $0.3 \mathrm{ng} / \mathrm{ml}$ plasma. Inter-assay variations were excluded since all plasmas were measured in the same assay. Intra-assay variation was no more than 10 p. 100.

Statistical analysis. - All the results were analyzed using variance analysis on a computer (GENSTAT programs) with the help of the Biometry Service (INRA, Jouy-enJosas, France) through the courtesy of Dr. C. Duhamel. Variance analysis was done using different mathematical models, the principal one being $y=\mu+$ pig + hour + day + pig.hour + pig.day + hour.day $+\sum$; this involved the inherent variations of each variate for every parameter, i. e. the variates of pig, day, morning/afternoon, diet, week and their interactions. For example, significant diet effects ( $\mathrm{Ca}, \mathrm{Mg}$ and CT) were observed due to the large number of determinations in spite of significant individual variation (" pig effect ») and a low number of animals. Linear correlations between variables were also obtained by the same program. The "Scheffé test" was used for comparison of multiple means (Scheffé, 1959).

\section{Results.}

Plasma calcium levels. - During the control period, mean plasma calcium values were $11.45 \mathrm{mg} / 100 \mathrm{ml}$ in the morning and $11.42 \mathrm{mg} / 100 \mathrm{ml}$ in the afternoon. A significant decrease in calcium was observed during the period of high phosphate diet only on afternoon values. The first significant decrease in plasma calcium concentration occurred 5 days after treatment with the high phosphorus diet (afternoon 5 on fig. 1). In the last 2 weeks of high phosphorus diet, hypocalcemia was greater than in the first one (10.79 and $10.31 \mathrm{mg} / 100 \mathrm{ml}$, respectively, vs. $11.05 \mathrm{mg} / 100 \mathrm{ml}$ ). During this dietary period, afternoon plasma calcium levels were significantly lower than morning values $(10.92 \mathrm{mg} / 100 \mathrm{ml}$ vs. $11.48 \mathrm{mg} / 100 \mathrm{ml} ; \mathrm{P}<0.01)$.

Plasma phosphorus levels. - There was no significant difference between plasma phosphorus levels of the control period and those of the phosphorus-rich period (fig. 1). Inter-pig variations were greater than for all other variates.

Plasma magnesium levels. - These levels significantly increased in the morning and afternoon during the first two weeks of high phosphorus diet, but returned to control values the third week (fig. 2). Mean levels of $2.23 \mathrm{mg} / 100 \mathrm{ml}$ were observed in the morning in the first 2 weeks of high phosphorus diet, as opposed to $1.96 \mathrm{mg} / 100 \mathrm{ml}$ in the control period $(P<0.01)$. Mean levels were also significantly higher $(P<0.01)$ in the afternoon during the first 2 weeks of high phosphorus diet $(2.27 \mathrm{mg} / 100 \mathrm{ml})$ than during the control period $(1.96 \mathrm{mg} / 100 \mathrm{ml})$. Significant peaks in plasma magnesium concentration occurred in the afternoon after 9 and 10 days of high phosphorus diet (fig. 2).

Plasma calcitonin levels. - There was no difference between morning and afternoon concentrations during the control period $(2.89 \mathrm{ng} / \mathrm{ml}$ versus $2.84 \mathrm{ng} / \mathrm{ml}$, respectively) (fig. 2). During the high phosphate period, plasma CT levels increased significantly in the morning and in the afternoon (fig. 2) (morning means: $5.09 \mathrm{ng} / \mathrm{ml}$ 


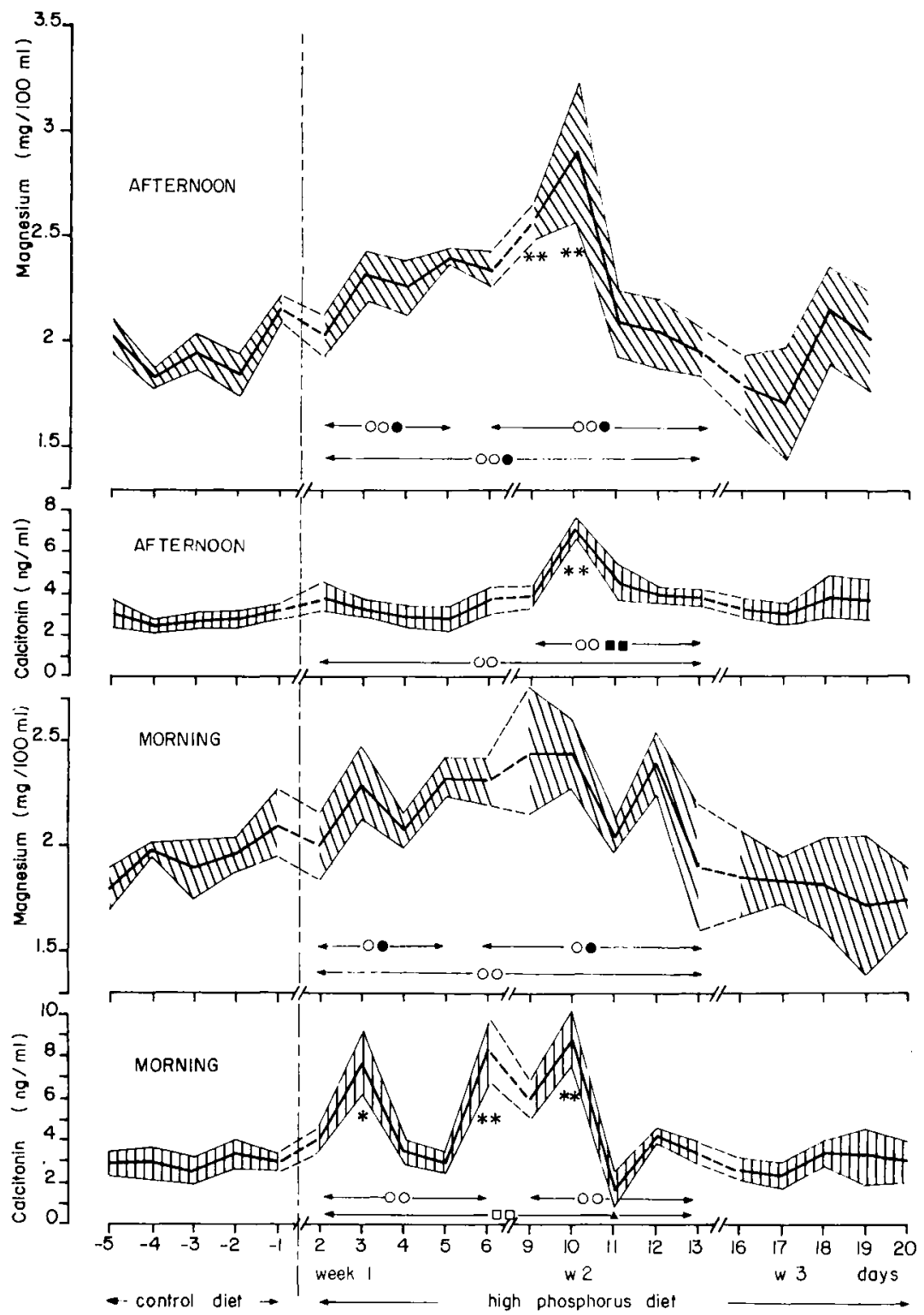

FIG. 2. - Morning (2 hrs after the meal) and afternoon ( $7 \mathrm{hrs}$ after the meal) plasma concentrations of magnesium and calcitonin in growing pigs fed a control and a high phosphorus diet ( $m \pm$ s. e. $m$.).

o significantly higher than control period : $\mathrm{P}<0.05 ; 00: \mathrm{P}<0.01$;

- significantly higher than last week : $P<0.05$;

- significantly higher than first week of high phosphorus diet : $\mathrm{P}<0.01$;

ם significantly higher than corresponding afternoon period : $\mathrm{P}<0.01$;

- significantly lower than days 3, 6, 9 and $10: P<0.05$;

** significant peak : $\mathrm{P}<0.01, * \mathrm{P}<0.05$. 
versus $2.89 \mathrm{ng} / \mathrm{ml}$ in control period, $\mathrm{P}<0.01$; afternoon means : $3.81 \mathrm{ng} / \mathrm{ml}$ versus $2.84 \mathrm{ng} / \mathrm{ml}$ in control period, $\mathrm{P}<0.01$ ). During the first 2 weeks of this diet, morning concentrations were higher than afternoon values $(5.09 \mathrm{ng} / \mathrm{ml}$ vs. $3.81 \mathrm{ng} / \mathrm{ml}, \mathrm{P}<0.01)$. The third week of the phosphate-rich diet, plasma CT levels were in the range of those observed during the control period. There was no day effect in the control period, but significant peaks in plasma CT concentrations were observed in the morning of days 3, 6 and 10 (fig. 2) during the high phosphorus period. A peak in CT also occurred in the afternoon of day 10 (fig. 2). On the morning of day 11, plasma CT levels tended to be lower than values observed the days before $(P<0.01$ when tested against peak values).

Plasma parathyroid hormone levels (fig. 3). - In the control period, means of morning and afternoon values were the same $(3.20 \mathrm{ng} / \mathrm{ml}$ in the morning versus $3.24 \mathrm{ng} / \mathrm{ml}$ in the afternoon). During the high phosphorus diet, morning plasma PTH levels were greater than afternoon values $(3.0 \mathrm{ng} / \mathrm{ml}$ versus $2.74 \mathrm{ng} / \mathrm{ml}, \mathrm{P}<0.05)$. Plasma PTH levels were significantly lower in the afternoon of the first 2 weeks of high phosphate diet $(2.74 \mathrm{ng} / \mathrm{ml}$ versus $3.24 \mathrm{ng} / \mathrm{ml}$ in the control period, $\mathrm{P}<0.01)$. The peak in plasma PTH concentration occurring in the morning of day 11 was higher than the other values but was only significant when compared to day $13(P<0.05)$.

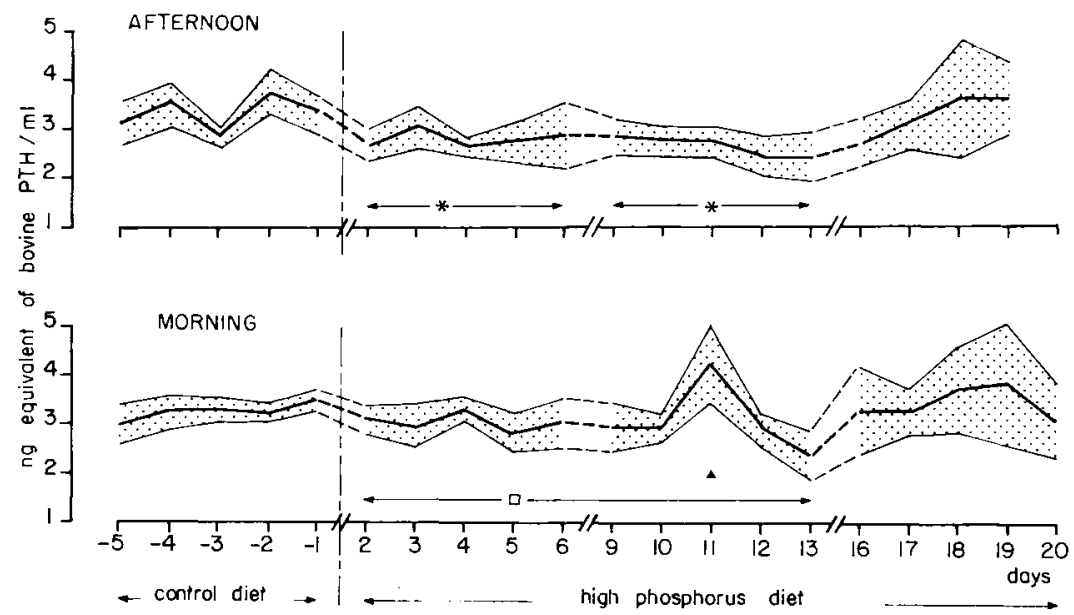

FIG. 3. - Morning ( $2 \mathrm{hrs}$ after the meal) and of fernoon ( $7 \mathrm{hrs}$ after the meal) plasma PTH concentrations in growing pigs fed a control and a high phosphorus diet $(m \pm s$. e. $m$.).

* significantly lower than control period : $P<0.05$;

a significantly higher than corresponding afternoon period : $\mathbf{P}<0.05$;

- significantly higher than day $13, P<0.05$.

\section{Discussion.}

Our data on pigs show that a high phosphorus dief induced a concomitant increase of plasma magnesium and calcitonin levels. Many reports have suggested that magnesium controls CT secretion in animals. Radde, Wittermann and Pensuwan (1968) 
demonstrated that a magnesium load in rats induced secondary hypocalcemia which did not occur in thyroidectomized animals. These results were confirmed in cats (Nielsen, 1970) and in cattle (Barlet, 1971). CT estimations by radioimmunoassay have led to the same conclusions since magnesium at concentrations of 4.4 to $12.7 \mathrm{mEq} / \mathrm{l}$, perfusing the porcine thyroid gland isolated in situ, stimulated CT secretion (Care, Bell and Bates, 1971). Similar results were reported by Pento ef al. (1974) and Cooper (1975) using in vivo preparations on pigs.

Our results agree with those previously reported in pigs since an increase of 20 p. 100 in plasma $\mathrm{Mg}$ level induced a threefold increase in postprandial plasma CT levels 2 hrs after the morning meal. This emphasizes that variations in plasma magnesium of nutritional origin might control CT secretion, especially in the postprandial condition. Whether hypermagnesemia or increased intestinal magnesium absorption stimulates plasma CT levels has not yet been determined. We are unable to explain why a high phosphorus diet could increase plasma magnesium level, but hypermagnesemia may result from a stimulation of intestinal absorption. In fact, the low urinary magnesium excretion (2.33 p. 100 of $\mathrm{Mg}$ intake) and the high intestinal magnesium absorption (1.9 g/day ; >50 p. 100 of $\mathrm{Mg}$ intake) observed in these experiments (Pointillart, unpublished) during the third and fourth week of high phosphorus diet, may simultaneously contribute to elevated plasma magnesium values. It has already been demonstrated in rats and goats that regulation of postprandial hypermagnesemia involves CT secretion (Barlet, Rayssiguier and Larvor, 1974). Furthermore, a positive correlation was found between plasma CT and magnesium levels in the morning $(r=0.33 ; P<0.05)$ and in the afternoon $(r=0.51 ; P<0.01)$, but only during the high phosphorus period. However, we cannot exclude the possibility that high phosphorus diet stimulates postprandial CT/secretion as observed after oral calcium administration in pigs (Cooper ef al., 1972) and in newborn lambs (Barlef et al., 1974 ; Garel, Savajol and Barlet, 1976). During administration of high phosphorus diet, CT levels were significantly higher 2 hrs after feeding than 5 hrs later, no difference being observed during the control period. This may be due to the meal effect of high phosphorus diet or to potentiation of postprandial CT secretion by hypermagnesemia. In rats fed high phosphorus diets, thyroid CT content increased progressively with the diets having a calcium to phosphorus ratio below $1: 1$, and elevated amounts of CT in sera and thyroid glands were found in rats fed diets with a calcium to phosphorus ratio of $1: 8$ (Clark, Hirsch and Cooper, 1976).

Afternoon plasma calcium concentrations, significantly lower than morning values during the high phosphorus diet, might be related to the high morning CT levels. Thus, it is tempting to speculate that morning hypermagnesemia stimulated postprandial CT secretion which decreased calcemia, this low level in turn inhibiting CT secretion in the afternoon.

Short-term experiments in adult rabbits (Jowsey and Balasubramanian, 1972) have shown that phosphate supplementation ( 2.05 versus $0.66 \mathrm{~g} /$ day) of dietary origin decreased plasma calcium level and increased plasma phosphate concentration after 4 and 8 weeks of treatment. A greater degree of bone porosity and soft tissue calcification were observed in these treated animals (id.). In growing pigs (20 to $90 \mathrm{~kg}$ ) hypocalcemia and hyperphosphatemia appeared after administration of high phosphorus diets (1.5 p. $100 \mathrm{P}$ and 0.8 p. $100 \mathrm{Ca}$ or 1.4 p. $100 \mathrm{P}$ and 0.35 p. $100 \mathrm{Ca}$ ) in long- 
term experiments (Brown, Krook and Pond, 1966). In young ponies, experiments carried out after 8 weeks of a phosphorus-rich diet (1.2 p. 100 versus 0.2 p. 100) demonstrated an increase in plasma phosphate and a decrease in plasma calcium associated with a rapid turnover of bone calcium (Schryver, Hintz and Craig, 1971). The existence of late secondary hyperparathyroidism was also suggested by the elevated plasma immunoreactive PTH levels found in dogs (Laflamme and Jowsey, 1972) after 5 months of a phosphorus-rich diet ( $2.8 \mathrm{~g}$ versus $1.0 \mathrm{~g} /$ day). In the present short-term experiments ( 3 weeks of phosphate supplementation), the plasma calcium and PTH levels decreased in the afternoon. At slaughter time, after 6 weeks of a phosphorus-rich diet, the plasma PTH level did not increase, but in three pigs the plasma CT level decreased. It should be emphasized that in the dog experiments of Laflamme and Jowsey (1972), plasma PTH levels in treated animals were not different from those observed in control animals 1 month after phosphate supplementation. Some authors have shown that hypermagnesemia suppressed parathyroid gland activity (Massry, Coburn and Kleeman, 1970 ; Radde, Wittermann and Pensuwan, 1968) and this might explain that in our conditions the high phosphorus diet increased plasma CT levels, whereas plasma PTH levels dropped. Thus, the simultaneously low plasma CT and magnesi um levels and significantly higher plasma PTH levels (fig. 2, 3 ; morning of day 11) are important and pertinent to our results. However, direct CT stimulation of PTH secretion in the morning of day 11 cannot be excluded since CT increases PTH secretion of porcine (Fischer ef al., 1971) and bovine (Abe and Sherwood, 1974) parathyroid glands in vitro. The high CT levels observed before day 11 might be a stimulus for PTH release when plasma magnesium level decreased. It must be remembered that the high phosphorus diet (1.15 p. 100) was richer in calcium than the control diet ( 0.77 p. 100 versus 0.55 p. 100$)$; thus, development of marked hypocalcemia and increased plasma PTH levels were probably inhibited.

Conflicting results were reported in the literature on the effects of high phosphorus diet on plasma phosphate. It was said to be due to the species studied, the stage of development (growing as opposed to adult or senescent animals), the calcium and phosphorus contents of the control and experimental diets used, and finally to the length of the experiments (short-term : 4-8 weeks vs. Long-term experiments : several months). According to Laflamme and Jowsey (1972), dogs maintained on high phosphorus diet for 10 months exhibited a decrease in plasma phosphate level 12 weeks after the beginning of treatment, whereas plasma calcium level was unchanged. However, serum inorganic phosphate increased in pigs fed over a long period (from 20 to $90 \mathrm{~kg}$; 3-4 months) (Bayley et al., 1975 ; Doige, Owen and Mills, 1975) ; a trend to hypocalcemia was also observed (Nielsen ef al., 1971). A long-term treatment of phosphate supplements in rabbits was without effect on plasma phosphate, but decreased plasma calcium level (Jowsey and Balasubramanian, 1972). Shah and Meranger (1970) failed to observe changes in plasma calcium and phosphate levels in weanling rats maintained on high phosphorus diet during short-term experiments. In the results reported here, there was no significant change in plasma phosphorus levels within 3 weeks of high phosphorus diet.

At slaughter, 6 weeks after the beginning of the high phosphorus diet, the kidneys showed evidence of nephrocalcinosis since the calcium content of these organs was increased (1.55 $\mathrm{mg}$ calcium/g fresh weight versus 0.09 in normals). A phos- 
phorus-rich diet is known to induce nephrocalcinosis in other species (Jowsey and Balasubramanian, 1972 ; Laflamme and Jowsey, 1972). Kidneys also have higher magnesium content than in normal pigs $(1.4 \mathrm{mg} / \mathrm{g}$ dry matter versus 1.0$)$. The temporary hypercalcitoninism observed during the first two weeks of phosphorus-rich diet did not protect the kidneys against subsequent nephrocalcinosis. Hyperparathyroidism might also be a cause of nephrocalcinosis in pigs (Boquist and Fahraeus, 1975), but our experiments did not show any increase in plasma PTH levels. Mclntosh and Scott (1975) suggested that in pig, adjustment of renal phosphate excretion in relation to filtered load is not dependent upon PTH. This study and the present work might signify that the role of PTH in this species is not so important as in other species.

We may conclude that dietary phosphorus supplementation of pigs induces temporary modifications in hormonal calcium-phosphate regulation, and especially the development of postprandial hypercalcitoninism. However, some of these modifications disappear two weeks after the introduction of the high phosphorus dief, and thus suggest an adaptation of the animal to the new diet.

Reçu en novembre 1977.

Accepté en janvier 1978.

Acknowledgments. - We particularly appreciate Dr. D. Duhamel's help on the statistical analysis and adaptation of the ANOVA model. We wish to thank Ms. Catherine Briand for the figures, Mr. Gauthier for his care of the animals and Ms. Alice Daifuku for the English translation. Drs. J. A. Parson and J. M. Zanelli (MRC, London, England) kindly gave us the purified bovine PTH. The Iniprol used was kindly supplied by the Laboratoire Choay, Paris, France. This study was supported by the ATP No 2417 of the Centre National de la Recherche Scientifique.

Résumé. Quatre porcs en croissance âgés de 10 semaines reçoivent un régime témoin contenant 0,6 p. 100 de phosphore, puis un régime contenant 1,15 p. 100 de phosphore (HP). Deux heures après le repas du matin et $7 \mathrm{~h}$ après, dans l'après-midi; les teneurs du plasma en calcium, magnésium, phosphore, calcitonine et parathormone sont mesurées, durant la période témoin d'une semaine, les 3 premières semaines du régime HP et à l'abattage, 3 semaines plus tard. La magnésémie et la teneur en calcitonine ont augmenté significativement durant les 2 premières semaines de régime HP, tandis que la teneur en parathormone a diminué légèrement l'après-midi. La calcitonine du matin était plus élevée que celle de l'après-midi durant la période HP et la calcémie était plus basse l'après-midi que le matin pendant la même période. Une corrélation linéaire positive a été mise en évidence entre le taux de $\mathrm{Mg}$ et celui de CT dans le plasma avec le régime HP. La phosphorémie n'était pas significativement modifiée par l'introduction du régime HP. Les changements des taux de $\mathrm{Mg}, \mathrm{CT}$ ef PTH n'apparaissent plus durant la $3^{\mathrm{e}}$ semaine de régime $\mathrm{HP}$, ce qui pourrait traduire une adaptation de l'animal. II est possible de penser que le régime HP induit des modifications temporaires de la régulation hormonale du métabolisme phospho-calcique et que l'hypermagnésémie post-prandiale stimule la sécrétion post-prandiale de calcitonine, ce qui a pour conséquence une diminution de la calcémie de l'après-midi. Ces résultats indiquent que l'effet repas du régime riche en $P$ ou l'hypermagnésémie d'origine nutritionnelle constatés dans cette expérience pourraient stimuler la sécrétion de calcitonine. 


\section{References}

ABE M., SHERWOOD L. M., 1974. Regulation of parathyroid hormone (PTH) secretion by factors other than calcium and magnesium, 238-245. In TAYLOR S., Endocrinology 1973, Proc. 4th int. Symp., W. Heinemann med. Books, London.

ANDERSON G. H., DRAPER H. H., 1972. Effect of dietary phosphorus on calcium metabolism in intact and parathyroidectomised adult rats. J. Nutr., 102, 1123-1132.

BARLET J. P., 1971. Role of the thyroid gland in magnesium-induced hypocalcemia in the bovine. Horm. Met. Res., 3, 63-64.

BARLET J. P., RAYSSIGUIER Y., LARVOR P., 1974. Action anti-hypermagnésémiante de la calcitonine chez le rat et la chèvre. C. R. Acad. Sci. Poris, Sér. D., 278, 2661-2664.

BARLET J. P., MICHEL M. C., THERIEZ M., SAVAJOL H., GAREL J. M., 1974. Calcitoninémie et effets métaboliques de la calcitonine chez l'agneau nouveau-né. J. Physiol., Paris, 68, 519-529.

BAYLEY H. S., ARTHUR D., BOWMAN G. H., POS J., THOMSON R. G., 1975 . Influence of dietary phosphorus level on growth and on development in boars and gilts. J. anim. Sci., 40, 864-870.

BOQUIST L., FAHRAEUS B., 1975. Renal morphology in pigs with experimental hyperparathyroidism. Light microscopic findings and some functional aspects. Acta pathol. microbiol. scand., Sect. A, 83, 131-138.

BROWN W. R., KROOK L., POND W. G., 1966. Atrophic rhinitis in swine. Cornell Vet., 56, suppl., 3-127.

CARE A. D., 1965. Secretion of thyrocalcitonin. Nature, Lond., 205, 1289-1291.

CARE A. D., BELL N. H., BATES R. F. L., 1971. The effects of hypermagnesaemia on calcitonin secretion in vivo. J. Endocr., 51, 381-386.

CLARK I., HIRSCH P. F., COOPER C. W., 1976. Alterations in thyroidal calcitonin content of rats fed diets of varying $\mathrm{Ca}: \mathrm{P}$ ratios. Proc. Soc. exp. Biol. Med., 153, 518-522.

COOPER C. W., 1975. Ability of several cations to promote secretion of thyrocalcitonin in the pig. Proc. Soc. exp. Biol. Med., 148, 449-454.

COOPER C. W., SCHWESINGER W. H., MAHGOUB A. M., ONTJES D. A., GRAY T. K., MUNSON P. L., 1972. Regulation of secretion of thyrocalcitonin, 128-139. In TALMAGE R. V., MUNSON P. L., Calcium, parathyroid hormone and the calcitonins. Proc. 4th Parathyroid Conf., Chapel Hill, 1971. Excerpta Med., Amsterdam.

DOIGE C. E., OWEN B. D., MILLS J. H. L., 1975. Influence of calcium and phosphorus in growth and skeletal development of growing swine. Canad. J. anim. Sci., 55, 147-164.

DRAPER H. H., TIEN-LIN SIE, BERGAN J. G., 1972. Osteoporosis in aging rats induced by high phosphorus diets. J. Nutr., 102, 1133-1142.

FISCHER J. A., OLDHAM S. B., SIZEMORE G. W., ARNAUD C. D., 1971. Calcitonin stimulation of parathyroid hormone secretion in vitro. Horm. Metab. Res., 3, 223-224.

GAREL J. M., BARLET J. P., 1976. A radioimmunoassay for bovine parathyroid hormone. J. Physiol., Paris, 72, 249-257.

GAREL J. M., CARE A. D., BARLET J. P., 1974. A radioimmunoassay for ovine calcitonin : an evaluation of calcitonin secretion during gestation, lactation and fotal life. J. Endocr., 62, 497-509.

GAREL J. M., SAVAJOL H., BARLET J. P., 1976. Plasma immunoreactive calcitonin levels in pregnant ewes and their lambs. Biol. Neonate, 28, 207-218.

GUEGUEN L., BESANÇON P., 1972. Influence des sulfates sur le métabolisme phosphocalcique : I. Utilisation du sulfate de calcium par le mouton. Ann. Biol. anim. Bioch. Biophys., 12, 589-598.

HUNTER W. M., GREENWOOD F. C., 1962. Preparation of ${ }^{131}$ l-labelled human growth hormone of high specific activity. Nature, Lond., 194, 495-496.

JOWSEY J., BALASUBRAMANIAN P., 1972. Effect of phosphate supplements on soft-tissue calcification and bone furnover. Clin. Sci., 42, 289-299.

LAFLAMME G. H., JOWSEY J., 1972. Bone and soft tissue changes with oral phosphate supplements. J. clin. Invest., 51, 2834-2840.

McINTOSH G. H., SCOTT D., 1975. Renal regulation of phosphate excretion in the pig. Quat. J. exp. Physiol., 60, 299-305.

MASSRY S. G., COBURN J. W., KLEEMAN C. R., 1970. Evidence for suppression of parathyroid gland activity by hypermagnesemia. J. clin. Invest., 49, 1619-1629. 
NIELSEN S. P., 1970. Abolition of magnesium-induced hypocalcaemia by acute thyroparathyroidectomy in the cat. Acto endocr. (Copenh.), 64, 150-158.

NIELSEN N. C., ANDERSEN S., MADSEN A., MORTENSEN H. P., 1971. Dietary calcium-phosphorus ratios for growing pigs in relation to serum level and bone development. Acta vet. scand., 12, 202-219.

PENTO J. T., GLICK S. M., KAGAN A., GORFEIN P. C., 1974. The relative influence of calcium, strontium and magnesium on calcitonin secretion in the pig. Endocrinology, 94, 1176-1180.

RADDE I. C., WITTERMANN E. R., PENSUWAN S., 1968. Effect of thyroid and parathyroid on hypocalcemia occurring after a magnesium load. Endocrinology, 83, 1255-1292.

SCHEFFÉ H., 1959. The analysis of variance, chap. 2, pp. 477, John Wiley and Sons, New York.

SCHRYVER H. F., HINTZ H. F., CRAIG P. H., 1971. Calcium metabolism in ponies fed a high phosphorus dief. J. Nutr., 101, 259-264.

SHAH B. G., KRISHNARAO G. V. G., DRAPER H. H., 1967. The relationship of Ca and P nutrition during adult life and osteoporosis in aged mice. J. Nutr., 92, 30-42.

SHAH B. G., MERANGER J. C., 1970. Effect of increased dietary phosphorus on calcium metabolism of young rats. Conod. J. Physiol. Pharmacol., 48, 675-680. 